Submission Politikon

Originally submitted March 2014

Revised version July 2014

\title{
Post-Liberation Democratic Authoritarianism: The Case of Namibia
}

Henning Melber*

ABSTRACT Namibia is praised as one of the most laudable democratic societies in SubSaharan Africa. But it also displays strong tendencies of autocratic political rule and intolerance with regard to views dissenting from the official "patriotic history" under the former liberation movement, the South West African Peoples Organisation (SWAPO of Namibia), since Independence transformed into Swapo Party.

This article summarises and seeks to explain the underlying social currents for this situation. By doing so, it also illustrates that a formally intact democratic system does not necessarily produce a fully democratic political culture - nor democrats, for that matter. A truly democratic break through for a pluralist society based on mutual respect despite different political opinions seems under the given circumstances of the Namibian society an unlikely development in the near future, notwithstanding the good marks the political system receives in international rankings for African democracies.

'Democracy cannot be build with the hands of broken souls.' ${ }^{1}$

\section{Introduction}

This article deals with the political hegemony in Namibia as an exemplary case study for testing the generally applied notions and definitions of democracy under a dominant party in the context of (Southern) African societies. It draws attention to a specific constellation under a former liberation movement, which has transformed into a dominant party executing socio-political control as government. ${ }^{2}$ While the next parliamentary and presidential elections will take place towards the end of 2014, their outcome is largely pre-determined: None of the observers have doubts that the dominance of the former liberation movement, governing since Independence in March 1990, will again be confirmed. But the wider debate on parties, democracy and political dominance in African states critically examining hegemonic structures has so far hardly ever included the 
Namibian case beyond forums confined to the sub-region. ${ }^{3}$ As a matter of fact, remarkably little attention has been paid in the more general literature to this particular case. A scholarly compilation of studies with the thematic focus on 'dominant political parties and democracy' does not even list Namibia in its index (Bogaards and Boucek 2010).4

In contrast, this contribution seeks to add further to the perspectives dealing with the 'limits to liberation' (Melber 2003a), comparatively explored also by Dorman (2006), contributions to De Jager and Du Toit (2013) and most prominently by Southall (2013) with regard to the cases of Zimbabwe, Namibia and South Africa. The analysis links to the recent debates over authoritarian forms of democracy, as among others promoted by Levitsky and Way (2002, 2010a and 2010b). Their meanwhile often debated and quoted concept of 'competitive authoritarianism' is defined as 'civilian regimes in which formal democratic institutions exist and are widely viewed as the primary means of gaining power, but in which incumbents' abuse of the state places them at a significant advantage vis-à-vis their opponents'. At a closer look, therefore, they are not truly democratic 'because the playing field is heavily skewed' (Levitsky and Way 2010a, p. 5). As these authors had stated already earlier on,

'many regimes have either remained hybrid or moved in an authoritarian direction. It may therefore be time to stop thinking of these cases in terms of transitions to democracy and to begin thinking about the specific types of regimes they actually are.' (Levitsky and Way 2002, p. 51)

It will be argued with reference to the case of Namibia, that this has only rarely so far been at the core of any analyses dealing with the political culture in this former settler colony. Rather, Namibia was so far mainly given credit on accounts of the liberal, constitutionally embedded side of society. But, as a review article observed, the recent debate has encouraged a re-thinking, thereby questioning 'the tendency to focus on the democratic-looking features of authoritarian regimes at the expense of, ironically, their authoritarian ones'. By doing so the debate has 'started to reverse a trend toward downplaying the coercive aspects of authoritarian regimes' (Art 2012, p. 369). 
On the other hand, one should not throw out the baby with the bathwater by simply replacing the one blind eye by another one. The ambiguity of democratic authoritarian regimes like the one in Namibia combines - nomen est omen democracy and authoritarianism in a specific blend, which represents elements of both. It hence is also to some extent a question of the kind of measurement, which underlies the conclusions, if and how far the verdict leans towards the one or the other end of the scale. As observed in the face of the growing literature on authoritarianism, the 'battle for democracy ... is being waged in more places and in a jungle of higher expectations' than ever before (Gilley 2000, p. 166). The case of Namibia is just one example among many. As the article suggests, the postliberation society represents an arena, in which democracy and authoritarian forms of rule are both integral features of the state and the political culture in existence.

Such seemingly contradictory but in the specific reality complementing elements of the forms of governance exist in differing degrees and nuances also in other former settler-colonial societies of the Southern African sub-region. Southern African liberation movements became governments as a result of their successfully conducted anticolonial resistance (including a relevant component of military action and sabotage) against settler minority regimes. ${ }^{5}$ While each of the cases is unique, they also share some commonalities. This is especially the case with regard to the negotiated transitions in Zimbabwe, Namibia and South Africa and the subsequent consolidation of the former liberation movements as political parties (cf. Dorman 2006, Southall 2013 and 2014). Somewhat disillusioned, Mamphela Ramphele - the former activist, then senior academic and high-ranking World Bank official (who failed in her rather naïve efforts to join South African party politics during 2013/14) - maintained in a lecture in September 2012, that, 'there is not a single post-liberation movement in Africa, perhaps in the rest of the world that has made the successful transition to democratic governance' (Ramphele 2012, p. 11).

Multiparty democracy in contrast to such diagnosis is understood as a form of governance, which empowers citizens to make choices among competing political agencies by freely electing and holding accountable their representatives, who obtain a 
mandate through their votes. Properly established and functioning autonomous institutions and civil society agencies would ensure that constitutional principles are respected and that checks and balances are applied in the public interest to those governing the state and running the bureaucracy as civil servants. Such conceptual ingredients have become at least the officially and formally accepted norm in the subregion since the end of colonialism. Independence and self-determination were consequently based on more or less legitimate forms of majority rule. Formal constitutional democracy has been embraced, which in principle provides a regulated and peaceful modus operandi for a change in governance and of governments.

The following parts concentrate on the specific socio-political structures and its culture emerging under the overwhelming dominance of Swapo as 'the prototype of an African catch-all party' (Elischer 2013, p. 262). ${ }^{6}$ By doing so, it isolates aspects of socio-political control and related mentalities as specific form of governance from any of the relevant other - not to a small extent external - factors, which in the first place secured transition to self-determination as negotiated controlled change, resulting in changed control.

The observations and arguments presented, however, deal purely with features of domestic policy and mindsets in the execution of the political power seized. They do not engage with these external factors contributing to the political, social and economic realities as influential factors. ${ }^{7}$ Rather, the forms of local agency are at the center. Those holding and executing political power are examined with regard to the degree, to which their political rule shows willingness to embrace democracy and civil liberties. After all,

'by taking the institutions of authoritarian regimes seriously, ... scholars are able to gain real traction on the question of durability. Rather than pointing to exogenous shocks, they are able to locate the reasons for authoritarian stability or breakdown in longstanding patterns of behavior, both formal and informal.' (Art 2012, p. 352)

\section{Namibia's “Minimalist Democracy" in Theory and Practice}

The contrast between compliance with formal criteria and actual practice is reflected in the fact that Namibia regularly ranks among the African countries in the best category for so-called good governance based on the indicators applied (such as freedom of the 
press, civil liberties, independent judiciary, regular and relatively free and fair elections etc.). The Freedom House Index for Political Rights and Civil Liberties Score in 2011 classified Namibia as free with an aggregate of 2 and 2 for both categories, which ranked it number four (jointly with Benin, Sao Tomé and Principe and South Africa) among all countries in the continent (Doorensplet and Nijzink 2013, p. 7). Similarly, the Mo Ibrahim Index released in October 2013 once again ranked Namibia favourably as number 6 at the top with a score of 69.5 out of 100 (directly after South Africa with 71.3/100), while the African average was at 51.6/100. It ranked fourth in rule of law, accountability and rights. ${ }^{8}$

Rudebeck (2011, pp. 7-8) makes the distinction between constitutional, 'minimalist' democracy 'conceptualized as a form of rule characterized by universal suffrage, regular elections and basic civil rights and democracy conceptualized as political equality in actual practice'. Swapo party's political rule can largely be characterized as democratic or competitive authoritarianism, in which

'elections are often bitterly fought. Although the electoral process may be characterized by large-scale abuses of state power, biased media coverage, (often violent) harassment of opposition candidates and activists, and an overall lack of transparency, elections are regularly held, competitive (in that major opposition parties and candidates usually participate), and generally free of massive fraud.' (Levitsky and Way 2002, p. 55)

In the introduction to their edited volume, Doorensplet and Nijzink (2013, p. 4) summarize Sartori's (1976) distinction between dominant (democratic) and dominantauthoritarian party systems, which Bogaards (2004, p. 179) had welcomed as an important differentiation applicable to the situation in African countries. Sartori suggests subdividing party systems into four types, ranging from dominantauthoritarian to dominant in a multiparty setting. This seems to imply that a multiparty setting would protect or prevent those executing political power from authoritarian forms of policy making and raises the question how authoritarianism is defined. The case made in this article is that despite all institutional provisions and structures in place, qualifying Namibia's political system as a full-blown multiparty democracy based on democratic constitutional principles, the actual policy executed has strong elements of what could be labeled democratic or competitive authoritarianism. With regard to 
the electoral dominance as 'a near permanent feature of the post-apartheid political landscape', Du Pisani (2013, p. 133) poses the question: 'To what extent can a constitutional regime with free and fair elections be regarded as a consolidated social democracy if one party is guaranteed a comfortable majority in apparent perpetuity?'

With Basedau (2007, p. 106) one is therefore tempted to ask, if there is 'a theoretically plausible and empirically systematic connection between party system characteristics and the democratic performance'. Referring to Dahl's concept of polyarchy (1971 and 1998) he opts for the liberal notion of democracy, 'characterized by high levels of competition and participation in the political system' in the absence of any credible alternative to such a concept (Basedau 2007, p. 113). He thereby dismisses any references to an 'African democracy' in contrast to democracy elsewhere. But subscribing to such approach, is then Namibia indeed a 'near best system' of a free and democratic society, as Basedau's ranking (2007, p. 131) suggests? He concludes that his findings differ from his original theoretical assumption by emphasizing polarisation as the most significant factor to distinguish between democratic and non-democratic party systems. He therefore emphasizes the need to develop and apply 'new measures for polarisation ... such as attitudes towards rival parties, behavioural patterns in parliament' and others (Basedau 2007, p. 132). A closer look the political culture under the Swapo government suggests, that 'doubts remain regarding to what extent the party has managed to overcome its legacy as liberation army' (Elischer 2013, p. 136).

The Super-super Dominance Syndrome: Swapo's One-Party Rule In his classification effort, Basedau (2007, p. 116) lists among others as a criterion for multi party systems 'to be moderately fragmented in order to ensure both stable government and relatively strong opposition'. This 'excludes one-party dominance and marginalization of opposition (either in terms of weak or highly-fragmented representation of opposition parties in the legislature)' (Basedau 2007, p. 117; his emphasis). He further qualifies high levels of one-party dominance as 'super dominance' if at least in two subsequent elections a two-third majority is obtained. According to this classification system, Swapo's track record (obtaining an absolute majority in the first 
elections in 1989, followed by two-third majorities in each of so far four consecutive elections as from 1994) documents that Namibia is blessed with a super-super dominance, as documented in Table 1 with regard to the elections results. ${ }^{9}$

Table 1: Parliamentary Election Results 1989-2009 for the Bigger Parties (absolute number of votes and percentage)

\begin{tabular}{|c|c|c|c|c|c|}
\hline Party & 1989 & 1994 & 1999 & 2004 & 2009 \\
\hline SWAPO & $\begin{array}{l}384,567 \\
56.90 \%\end{array}$ & $\begin{array}{l}361,800 \\
73.89 \%\end{array}$ & $\begin{array}{l}408,174 \\
76.15 \%\end{array}$ & $\begin{array}{l}620,609 \\
75.83 \%\end{array}$ & $\begin{array}{l}602,580 \\
74.29 \%\end{array}$ \\
\hline DTA & $\begin{array}{l}191,532 \\
28.34 \%\end{array}$ & $\begin{array}{l}101,748 \\
20.78 \%\end{array}$ & $\begin{array}{l}50,824 \\
9.48 \%\end{array}$ & $\begin{array}{l}42,070 \\
5.14 \%\end{array}$ & $\begin{array}{l}25,393 \\
3.13 \%\end{array}$ \\
\hline UDF & $\begin{array}{l}37,874 \\
5.60 \%\end{array}$ & $\begin{array}{l}13,309 \\
2.72 \%\end{array}$ & $\begin{array}{l}15,685 \\
2.93 \%\end{array}$ & $\begin{array}{l}30,355 \\
3.71 \%\end{array}$ & $\begin{array}{l}19,489 \\
2.40 \%\end{array}$ \\
\hline COD & - & - & $\begin{array}{l}53,289 \\
9.94 \%\end{array}$ & $\begin{array}{l}59,464 \\
7.27 \%\end{array}$ & $\begin{array}{r}5,375 \\
0.66 \%\end{array}$ \\
\hline RDP & - & - & $\begin{array}{l}- \\
-\end{array}$ & $\begin{array}{l}- \\
-\end{array}$ & $\begin{array}{l}90,556 \\
11.16 \%\end{array}$ \\
\hline
\end{tabular}

As Table 2 shows, the composition of opposition parties and their strength had internal variations but remained since 1994 almost identical. Inner-party political differences ahead, during and after the party congresses of 1999 and 2004 took forms of a witchhunt, when the fall-out resulted with the CoD (1999) and the RDP (2007) in the formation of two new political parties. The vendetta resembled features of the McCarthy era. Several declarations of individuals publicly stating that they are wrongly accused of affiliations to the new party in the process of being established testified to this in both cases. The purge of suspected CoD and then RDP sympathisers, denounced as "hibernators", resulted in several higher-ranking political office bearers, civil servants and senior staff at state owned enterprises being unceremoniously axed. ${ }^{10}$ Despite initial relative successes, the new parties did not in any decisive way impact on the balance of political power, but rather added to a re-distribution of votes among the opposition parties.

Table 2: Opposition Votes in National Assembly Elections

\begin{tabular}{lcccc} 
Year & Total votes & Opposition votes Percentage & \multicolumn{2}{c}{ Seats (of 72) } \\
1989 & 680,787 & 286,263 & $42 \%$ & 31 \\
1994 & 497,508 & 127,836 & $26 \%$ & 19 \\
1999 & 541,114 & 127,862 & $24 \%$ & 17 \\
2004 & 829,269 & 197,830 & $24 \%$ & 17 \\
2009 & 811,143 & 197,987 & $25 \%$ & 18
\end{tabular}

As Kaapama et. al. (2007, p. 92) concluded, 'a weak opposition has contributed 
significantly towards one-party dominance.' This allows Swapo to use (if not to abuse) the state institutions for its further consolidation and to apply democracy in a way that strengthens the party even more. The strictly proportional financial support allocated to the parties from state revenue as documented in Table 3 is a case in point (extrapolated from Du Pisani and Lindeke 2009, p. 23).

Table 3: Party Financing from Public Funds (in million N\$)

$\begin{array}{lcccccccr}\text { Party } & & \mathbf{2 0 0 0 / 0 1} & \mathbf{2 0 0 1 / 0 2} & \mathbf{2 0 0 2 / 0 3} & \mathbf{2 0 0 3 / 0 4} & \mathbf{2 0 0 4 / 0 5} & \mathbf{2 0 0 5 / 0 6} \\ \text { SWAPO } & 9.6 & 10.8 & & 13.8 & 14.7 & 12.2 & 11.7 \\ \text { Others (total) } & & 2.9 & 3.3 & & 4.2 & 4.4 & 3.7 & 3.5\end{array}$

This provides Swapo with an enormous advantage in material terms over all other political competitors, not only by means of much higher state subsidies, but also by having free access to state infrastructure and assets for party-political mobilization. ${ }^{11}$ This constellation confirms the argument that 'dominant parties win despite genuine electoral competition because the incumbent's resource advantages and the costs it imposes on challengers make elections substantially unfair' (Greene 2010: 155). In addition, the plural, multiparty character of Namibia's political system contrasts with the lack of substantive political-ideological differences among the major parties. As a result, 'electoral competition has never revolved around policy issues' (Cooper 2014, p. 112). As observed by Basedau (2007, p. 126) for African countries generally, 'party manifestos and programmes do not play a significant role'. Neither does a specific ideology influence the Namibian political party manifestos (Hunter 2005) beyond the heroic narrative cultivated by Swapo's patriotic history (Melber 2003b, 2003c and 2005a). In the absence of any significant programmatic confrontation, the concept of polarisation advocated by Sartori's typology (1976), might therefore 'not be at all relevant' and would require 'a small modification which places more emphasis on the mode of behavior and relationship between the parties than on ideological distance' (Erdmann et. al. 2007, p. 283). As is suggested by Cooper (2014, p. 112), 'opposition parties accept and indeed perpetuate their own marginalisation'.

As a result, there is a diverse but ineffective opposition (Melber 2010 and 2013). While the facade of a vibrant civil society is retained or fostered, in-fights within and 
among the various opposition parties continue to erode any meaningful contribution to the democratic process (Melber 2009b). Most, though not all, of the numerous opposition parties in Namibia qualify in the sense suggested by Greene (2010:155) 'as niche-oriented competitors that make specialised appeals to minority electoral constituencies'. The challenges to Swapo's rule therefore have remained few, inefficient and isolated. Given this sobering situation, 'it would be a mistake to absolve opposition parties of all responsibility for the reproduction of single-party dominance' (Cooper 2014, p. 118). The main interest of many leading politicians from other parties seems to be focused on obtaining a well-paid seat in the National Assembly to secure a privileged status and living. This is for the top ranked candidates even among the small parties a realistic aspiration, given that the proportional electoral system offers parties with less than one per cent of votes a parliamentary representation. Based on this constellation and the lacklustre performance of opposition parties both in parliament as well as in the public discourse, Cooper (2014, p. 127) concludes: 'if the process of challenging and overcoming single-party dominance is a marathon, Namibia's opposition parties have been given up at the starting line'.

By far the most spectacular albeit irredentist challenge of the state happened in August 1999. After some incubation period of politically voiced frustration, a secessionist movement in the north-eastern region of the so-called Caprivi Strip - an inherited geographical monstrosity as a result of colonial transactions with a markedly local identity separate from the unitary state - resorted to a limited and isolated armed insurrection in pursuance of the demand for self-governance (Melber 2009c). The Namibian security forces quickly ended the desperate and ill fated, misguided rebellion and arrested many suspects under charges of high treason. Local activists in support of autonomy for this region continued to mobilize within the United Democratic Party (UDP), which dissociated its activities from any violent means. The government declared the party illegal with effect of 1st September 2006 (IRIN 2006). ${ }^{12}$

Despite such disturbing "hiccups", which suggested that not all is well in the state of Namibia, the official results announced by the Electoral Commission of Namibia (ECN) in early December 2009 for the fifth legislative period of the National Assembly starting in March 2010 (see Table 4) ${ }^{13}$ once again confirmed the hegemonic status of 
Swapo. Although the official figures as well as parts of the electoral procedures were subsequently contested in court without success, nothing had changed in terms of the fundamental power relations. None of the seasoned observers had, despite the legal interventions, expressed any doubts that Swapo remained the undisputed political representative of the majority of the Namibian people.

Table 4: National Assembly Election Results 2009

\begin{tabular}{|c|c|c|c|c|}
\hline Party & \multicolumn{2}{|r|}{ Votes } & $\%$ & Mandates \\
\hline SWAPO Party of Namibia (SWAPO Party) & 602,580 & 74.29 & & 54 \\
\hline Rally for Democracy and Progress (RDP) & 90,556 & 11.16 & & 8 \\
\hline DTA of Namibia (DTA) & 25,393 & 3.13 & & 2 \\
\hline National Unity Democratic Organization (NUDO) & 24,422 & 3.01 & & 2 \\
\hline United Democratic Front of Namibia (UDF) & 19,489 & 2.40 & & 2 \\
\hline All People's Party (APP) & 10,795 & 1.33 & & 1 \\
\hline Republican Party of Namibia (RP) & 6,541 & 0.81 & & 1 \\
\hline Congress of Democrats (COD) & 5,375 & 0.66 & & 1 \\
\hline South West Africa National Union (SWANU) & 4,989 & 0.62 & & 1 \\
\hline Monitor Action Group (MAG) & 4,718 & 0.58 & & 0 \\
\hline Democratic Party of Namibia (DPN) & 1,942 & 0.24 & & 0 \\
\hline Namibia Democratic Movement for Change (DMC) & 1,770 & 0.22 & 0 & \\
\hline National Democratic Party (NDP) & 1,187 & 0.15 & & 0 \\
\hline Communist Party (CP) & 810 & 0.10 & & 0 \\
\hline Rejected Ballots & 10,576 & 1.30 & & \\
\hline Total & & 811,143 & 100.00 & 72 \\
\hline
\end{tabular}

Swapo's dominance was further consolidated by the local and regional elections held $26 / 27$ November 2010. A disappointing turn out of $38.6 \%$ of registered voters did not dampen Swapo's elation at clenching absolute majorities in all but one of the 13 regional councils. Only in a few pockets particularistic (ethnically) motivated local leaders and parties managed to obtain some support. The 13 regional councils feed the National Council, where each of them has two representatives. In 2010 Swapo obtained 98 out of 107 seats, the DTA 2, UDF 3, RDP 1 and NUDO 3. Notably, both UDF (Damara) and NUDO (Herero) garner their votes in ethnical-local strongholds. As Elischer (2013) pointed out, such forms of ethnic parties affect democratic competition and choice 
negatively and reduce elite responsiveness, since the challenges are not posed on a level of alternative national policies.

Preempting any potential reduction of control on a local or regional level, the Special Advisors and Regional Governors Appointment Amendment Act, No. 20 of 2010, collided with - if not openly violated - the constitutionally enshrined principles of autonomy vested in the regional and local government bodies. ${ }^{14}$ It delegated the appointments of regional governors to the discretion of the head of state and thereby removed this decision from the (elected) members the regional councils. This allows for the appointment of a Swapo party representative as governor of a council with a nonSwapo majority (which indeed happened in the case of the Kunene region). The rationale given was the intention for an effective implementation of the party's 2009 Election Manifesto. But in actual fact, 'the Regional Governors have become little more than the former 'Bantu Commissioners' in a system of neo-patrimonial and indirect rule' (Du Pisani 2013, p. 140).

In the light of such a constellation, which shows the weakness of an incapacitated political opposition, the most important feature in terms of political contestations seems to be the inner-party competition, power struggles, factionalism and rivalry with regard to control over the party machinery. Decisions within the party over succession and replacements at higher party levels are decisive also for issues relating to the government and state policies. This merits a closer look at the degree of inner-party democracy, which - some might argue - could compensate or replace the pluralist character required within a democratic society. The answer is however rather disappointing: for Elischer (2013, p. 136), the party's 'relationship with intra-party democracy is complicated at best'. As Giollabhui (2011, p. 594) observes, the 'democratic stock' of Swapo Party is 'extremely low'. His comparative analysis of candidate selection for the party lists for parliamentary elections by the ANC and Swapo in 2004 showed that Swapo members and their delegates at the party congress - in sharp contrast to the ANC - 'played second fiddle to a relatively small coterie of party notables, including the powerful party leader'. The contestation over the construction of the party list at the congress in 2004, resulting ultimately in the defection of the losing group and the establishment of a new party, was bitterly contested and 'deeply 
undemocratic' (Giollabhui 2011, p. 595). So was the battle over the succession of the first president in office (Melber 2006, Elischer 2013, pp. 127f.), who - due to the first change of the Constitution - was allowed to serve three terms from 1990 until 2005. It demonstrated and underlined the point stated succinctly by Levitsky and Way (2002, p. $59)$ that, 'succession is not democratization'.

The 'locus of control' (Basedau et. al. 2007, p. 279) clearly rests in the Namibian case with the party leadership proper, not the MPs, who in their majority are as ministers or deputy ministers not really tasked to control the executive and are actually in large parts identical with the party leadership (Melber 2005b). This is a leadership, which still resembles despite some retirements and fall-outs more than twenty years into Independence to a large extent the "struggle generation" and hence suggests very limited intra-party upward mobility. As a frustrated observer noted on the popular forum of the "SMSes of the Day", published on 14 October 2013 by the newspaper "The Namibian":

"I lived in exile in the mid-70s as a teenager that time. We used to be reminded each time we had morning parades in Swapo camps that we are the youth and the leaders of tomorrow. We were reminded by the same faces I still see today as leaders after almost 40 years and more in leadership positions. When are they going to loosen, let alone, step down from these positions?"

\section{Features of the Authoritarian State and Mindset}

As shown, the 'SWAPO Kingdom' (Elischer 2013, p. 17) was never seriously challenged - even though the newly formed breakaway parties claimed to be political alternatives. Represented by contestants with "struggle credentials", who previously held political offices in Swapo, the CoD and the RDP emerged as new but rather temporarily relevant elements. Their appearance caused intense debates and a tense atmosphere, but they had ultimately only limited impact in terms of the party political landscape or rather distribution of votes among the electorate. In contrast, the impact in terms of the polarized political climate was much bigger. In the eyes of Swapo and its clientele they were dismissed as provocateurs, as neo-imperialist pawns, as traitors, as prophets of doom or simply as misguided elements. The way the 2009 election results were commented on the Swapo party web site is indicative: 
'They have dealt a blow to the hallucinations of RDP and NSHR (the National Society for Human Rights; HM) as well as their sponsors. RDP and NSHR are projects of imperialists. The masters are seated elsewhere (specifically those in Germany) plotting and planning how SWAPO as a liberation movement should be removed from the political landscape of Namibia. It is called regime change.' (SWAPO Party 2009)

The ostracizing of political dissidents at times borders to the absurd. ${ }^{15}$ So does the interpretation of the liberties within the stipulated constitutional powers of the executive president. At the party congress held in November 2012, the newly elected party secretary general abandoned his previous ministerial rank to devote his full time to party affairs. He subsequently was appointed as a member of cabinet by the party president and head of state Hifikepunye Pohamba. The concerns raised by a scholar at the University of Namibia's Faculty of Law were dismissed by the editor of the party's weekly newspaper "Namibia Today" in his column "Zoom In":

'Public Law Professor, Nico Horn, (...) argued in a local English daily this week that President Hifikepunye Pohamba was "confusing the party with the government." The launching pad for his vitriolic attack was President Pohamba's decision to keep SWAPO Party Secretary General, Cde Nangolo Mbumba, as a member of Cabinet. (...) there is nothing scandalous or unconstitutional about Cde Mbumba sitting in Cabinet. The only scandal ... has been Professor Horn's pathetic understanding of the powers of the President as enshrined in the Constitution.' (Ntinda 2013a)

Such defence of an all-mighty president of party and state, who holds the power of definition over what governance means and how it is best achieved in the interest of the party (being equated with "the people") contrasts markedly with the formal constitutional principles. The web site of the government of Namibia introduces not only the Cabinet but also quotes Article 35 of the Namibia Constitution with regard to its composition. - Notably, and in striking contrast to the definition offered by the party newspaper's editor, there is no provision allowing the president appointing any party official not holding office as minister to join cabinet. ${ }^{16}$

Namibia fully embraces in its normative frameworks the legal franchises of a democratic state: universal suffrage, regular elections, legal guarantees for national civil and human rights, the right to associate and organise as well as legal protection against the haphazard exercise of power. Several examples however illustrate that these formal 
and legal aspects of the democratic state are at times ignored or bypassed. Informal and shadow networks that are controlled by the liberation party and its 'party machine' (Southall 2013) but exercised through the state apparatus are applied to promote own gains, but also to repress opposition by means of a skewed playing field.

Groomed within a mentality of entitlement, government officials and political office bearers have repeatedly used state assets (such as the infrastructure and material of ministries) for party political activities, including preparations for party congresses and related events. During the first week of July 2009 (some four months ahead of the parliamentary and presidential elections), party and state president Pohamba toured several places in a combination of mainly party political mobilization and - to a lesser extent - in pursuance of official duties (Maletsky 2009). His travels were arranged by state house and conducted by state financed transport, accompanied by a large entourage of civil servants. Being critically interrogated by an editorial carried in the independent newspaper "The Namibian" over the possible abuse of taxpayers' money for party-political purposes, the official response from the Permanent Secretary of the Ministry for Information and Broadcasting in his role as spokesperson for the government was that as Head of State President Pohamba is on duty 24/7 (UaNdjarakana 2009). President Pohamba also hosted an exclusive fundraising dinner for Swapo in the State House in November 2012 to generate funds for the forthcoming party congress. Reportedly, some 20 business people were offered a seat at the President's table for a party donation of at least $N \$ 100,000 .-$ (then approximately $€$ 10,000) each (The Namibian 2012). ${ }^{17}$

A similar culture of exclusive entitlement to associate public service with the party as sole gatekeeper for access to such services was displayed at a community meeting in late October 2013 in one of the shack dwellers sites in the Windhoek township of Katutura. Residents were reportedly told to attend the meeting, which would address challenges such as water, electricity and service delivery and elect a committee representing the community. But when showing up, residents were asked to show their Swapo membership cards to be able to attend and speak, since the participation in the committee would require Swapo membership. Allegedly, Swapo membership cards were sold to those who wanted to join the meeting. According to a 
frustrated witness, 'the organisers of the meeting introduced themselves as municipal staff, while the person who officially led the meeting, ... a Swapo Party Women's Council coordinator, told all who were present that their issues will not be addressed unless they were members of her party.' (Tjihenuna 2013)

The equation that the party is the government and the government is the state and that for the rest of time - is deeply entrenched in the mind of the Swapo leaders as well as in most of their support base. When addressing the annual congress of the party's Youth League in 2010, the former Namibian head of state Sam Nujoma, who was upon retirement bestowed the official title "Founding Father of the Namibian Nation" by the party's majority in parliament, ended his speech with the appeal:

'As Namibian youth, and as Africans, you must therefore be on the full alert and remain vigilant against deceptive attempts by opportunists and unpatriotic elements that attempt to divide you. As the future leaders of our country, you should act with dedication and commitment; to always promote the interests of the SWAPO Party and the national interests before your own. It is only through that manner that the SWAPO Party will grow from strength to strength and continues to rule Namibia for the next ONE THOUSAND YEARS.' (Nujoma 2010; capital letters in the original)

Not surprisingly in the light of such tones, empirical evidence suggests that democracy has not been implemented beyond what Rudebeck (2002 and 2011) terms 'democratic constitutionalism'. He criticises the minimalist form of democracy for not, on its own, being able to achieve the more substantive form of democracy as political equality in actual practice (Rudebeck 2011, pp. 7-8). Given the features of the current democracy in Namibia, and contrasting it with such parameters, it seems indeed no exaggeration to qualify it as 'unfinished business' (Sims and Koep 2012).

\section{Democratic Authoritarianism}

Doorenspleet and Nijzink (2013b, p. 202) explain the cases of enduring dominance by dominant parties by 'the fact that they continue to be associated with important historical legacies, that they are well organized and deeply rooted political movements, and that they successfully manage leadership change and succession'. The Swapo party has scored remarkably well in all three categories. Transforming the liberation movement into a party, which more than 20 years into post-colonial governance is still 
to a large extent dominated and controlled by the first generation of the liberation struggle's leadership is no minor achievement, though it comes at a price. Not only provided the continuity a welcome stabilizing factor in the institutionalization of the new state, and allowed for a relatively smooth and unspectacular establishment of a new order, which 'balanced the demands of institutional reform with continuity' (Dorman 2006, p. 1097). At the same time it promoted complacency in combination with a proclaimed and strongly guarded exclusivity, which encouraged a lack of delivery. There emerged a 'more exclusivist mode of autocratic rule, continuing to draw on tropes of liberation, development and democracy, but which increasingly appear perverted' (Dorman 2006, p. 1099). As a result of such a mold, the symbolic narrative based on the struggle credentials superseded 'considerations of uneven delivery in a number of policy domains, and as such resembles a 'founding myth' in terms of which the Party and the post-apartheid State share a moral and historical assignation' (Du Pisani 2013, p. 136).

The hybrid mix of authoritarianism and democracy disguised as specific form of 'nationalism and national projects' (Ndlovu-Gathseni and Ndhlovu 2013) has been normalised in the post-colonial settings. A key feature has been an appetite for more power and private self-enrichment through occupying the political commanding heights of party, government and state. This resulted in the willingness to also resort to the continued use of structural violence, which includes the disrespect for if not repression of individuals' civil rights, as well as threats to their personal physical integrity. It is perpetrated in the form of police brutality but under the guise of enforcing law and order; systematic exclusion from economic gains through systems of patronage and corruption; vendettas against the media and individual journalists critically commenting; naming and shaming individuals with differing opinions; restricting other political parties or collective initiatives in their right to gather; and practising excessive presidential powers that overrule the democratic running of the state in favour of the ruling party. The liberation party has a symbiotic relationship with the state security apparatus (military, police, prisons, intelligence), and its leading officers, who were mainly recruited from within the securocrats in the ranks of the liberation movement.

The locally well-known connotation between policy and security organs weighs 
in when the rhetoric sable rattling through party hardliners seeks to intimidate and thereby silence dissenting views. It is a reminder that coercive practices mobilising fear, are an integral part of such authoritarian democracy. The editor of the Swapo party weekly newspaper "Namibia Today" provided another example for such practices when in September 2013 he was targeting in his column mainly two white activists, who were also involved in the anti-colonial struggle prior to Independence. Perceiving their criticism of governance practices as a sign of concerted efforts to bring the 'government under attack', the comment fumes inter alia:

'Leading the pack in this unholy alliance is an assortment of some uppity whites, which, unfortunately, still believes that it is the white men's burden to "civilize" the "natives" and teach them not only about democracy, but also how to behave and how to spend taxpayers' money. (...) It is time both ... zipped their mouths themselves. Or someone else will have to zip their mouths for them.' (Ntinda 2013b)

This unveiled threat documents the allergic reactions to any criticism of Swapo and the government's policy and practices and shows the limits to a democratic pluralism including the freedom of speech. Such open intimidation through the official organ of the party, practiced regularly by its editor, seems to confirm the saying: In African democracies there is freedom of speech but what may not be guaranteed is freedom after the speech.

The use of structural violence as a form of "democratic authoritarianism" in Namibia undermines the virtues of democracy as political equality in actual practice. Scholars have been writing on structural violence ever since the pioneering analyses by Johan Galtung (1969) in various socio-political settings. They have viewed it as operating behind the façade of formal state institutions. Structural violence in this sense is an invisible hand, embedded in ubiquitous social structures, apparently normal since manifested by stable institutions and based upon regular experience. Because of their lasting nature, structural inequities seem ordinary. They are perceived as the way things are and always have been. This more sophisticated execution of structural violence is not practised in Namibia, where it manifests itself much more openly by a lack of checks and balances, weak institutions, practices of exclusion, control over agencies supposedly tasked to act independently from the governing bodies and political authorities and so on. While the Namibian judiciary remains so far to a large 
extent independent and the constitutional principles mainly respected, Namibia's electoral commission is in contrast an interesting case to document the limited extent of being are truly independent body. Rather, it is controlled by the government and mainly filled by political appointees.

While political parties are instrumental organisations that are indispensable ingredients for democratic development and modern politics (Bogaards 2000; Lipset 2000; Salih 2003), analyses on the limits of liberation (i.a. Melber 2003a and 2009a; Southall 2013) show that parties that fought liberation wars against settler colonies in southern Africa have tended to emulate their colonial foes once in power and continue to use structural violence as a means of governance. Mehler (2007, p. 196) maintains that in the case of victorious liberation movements ... "violent actors" are the ones in power and their continuous ability to mobilise means of violence beyond any constitutional restrictions is an integral part of "the system"'. This might be less obvious and visible in the Namibian case than in others he mainly refers to. But the resort to violence is not eliminated as a variable in the system of political practice. It remains a residual category that could be mobilised as an integral part of the "struggle mentality" surviving in the sublime underbelly of a former liberation movement as party in control of government. The forms of governance cultivate a patriotic history based on the narrative that the dominant party achieved victory through the barrel of a gun and remains the 'sole and authentic representative of the Namibian people' (Melber 2004; see also Melber 2003b and 2005a). As observed more generally by Elischer (2013, p. 273): 'The structural conditions in which African parties strive are still conducive to the survival of nondemocratic norms.'

Indeed, already Fanon (2001) had in a chapter on the 'pitfalls of national consciousness' warned more than half a century ago of the setbacks to proclaimed emancipation through post-colonial authoritarianism under the banner of liberation by means of revolutionary power. Randall (2007, pp. 101f.) even questions with regard to movement parties in the tradition of such anti-colonial struggles 'how far from the point of view of social groups themselves, or even democracy, it is desirable that such parties should be allowed to take on responsibility, certainly exclusive responsibility'. With reference to the liberation movements as political parties in power in Southern Africa, 
this is of course a purely hypothetical reasoning without any relevance for the sociopolitical realities, though it touches on a taboo. As Erdmann et. al. (2007, p. 289) conclude,

'The question is whether the violence of the liberation had a lasting impact on the structure and behaviour of these political parties. One obvious assumption is that the military organisation required by the liberation war is difficult to transform into a civil and democratic organisation. One consequence might be a lasting authoritarianism.'

The particular tension produced by the legitimacy to govern contrasted with the absence of strong control over the adherence to truly democratic practices and forms of governance. This tension is not unique to Namibia. But here it has produced specific legitimacies and heroic narratives seeking to camouflage and justify the hegemonic rule. This has led to the continuous open use of structural violence against those that challenge the liberation party's legitimacy. The underlying general understanding is that seizing political power after a long struggle signals "the end of history" in as much as any future policy shifts in governance would merely reflect the changing power structures within the governing party. A general, almost logical political feature as a result of this claim to exclusivity and entitlement is the intolerance to diversity. This can be traced back to the liberation struggle when the liberation movement with quite diverse members enforced a form of conformity by suppressing differences and arguing that unity was necessary for nation building in the post-independence period (see i.a. Leys and Saul 1995; Dobell 1998). Thus, to such liberation parties', whose members were socialised in and used to underground behaviour requiring and demanding strict discipline and absolute loyalty, non-conformity, diversity and even mild criticism was seen as tantamount to betrayal of the "family". They dealt with such non-compliance with the established norms and code of conduct by strict punishment of deviating behaviour (Suttner 2008). These continued practices have weakened further already weak opposition parties, who are ambitious to take the reigns of government only to practice a similar system of political dominance (Melber 2009a, 2011a and 2011b). As a result, they hardly manage to convince the electorate that they would be a credible alternative for which it would be justified to take any personal risks of being branded as "unpatriotic traitor" or "dissident" promoting regime change for neo-imperialism. 


\section{Authoritarian Rule by Democracy or Democracy by Authoritarian Rule?}

While there has been a proliferation of research on hybrid regimes, most scholars have focused on its theorisation (see i.a. Lindberg 2004 and 2006; Bogaards 2009; Regan and Henderson 2002; Coppedge and Gerring 2011). The empirical work on hybrid regimes seeks to explain how they work and not what regime types they constitute, and there has been mainly a focus on the West African region within the continent. No real systematic attention has however so far been paid to the empirically complex political practices that are manifested in forms of structural violence and their consequences to attaining democracy as political equality in actual practice, in the sub-region of Southern Africa under former liberation movements as governments. Their trajectory translates into a specific form of authoritarian rule. The case of Namibia offers a wide range of evidence that testifies to this. While Levitsky and Way (2010b) selected with Kenya, Mozambique, Zambia and Zimbabwe four somewhat not only geographically related case studies, they missed out on Namibia as maybe even the best of these examples to support their hypothesis:

'The most durable party-based regimes are those that are organized around nonmaterial sources of cohesion, such as ideology, ethnicity, or bonds of solidarity rooted in a shared experience of violent struggle. In particular, parties whose origins lie in war, violent anti-colonial struggle, revolution, or counterinsurgency are more likely to survive economic crisis, leadership succession, and opposition challenges without suffering debilitating effects.' (Levitsky and Way 2010b, p. 3)

As they conclude: 'Revolutionary or liberation struggles also tend to produce a generation of leaders ... that possesses the necessary legitimacy to impose discipline during crises'. Hence 'new ruling parties that emerged from violent struggle, such as SWAPO in Namibia, ... appear to be more durable' (Levitsky and Way 2010b, pp. 44 and 45). Gyimah-Boadi (2007, p. 25) reminds us, that parties in most African countries 'are hardly conceived and developed as mechanisms for representation, conflict resolution, opposition and accountability, or institutionalization of democratic behavior and attitudes'. - But then, after all, where fulfil parties such functions in our times any longer anyway? It hence ought to be no surprise that in the absence of any genuine and credible alternative, in the spirit of the "struggle days" and one of its most popular slogans ('SWAPO is the nation and the nation is SWAPO') the former liberation 
movement as a party remains to a large extent the nation, and the nation to a similarly large extent remains Swapo. - It is an entirely different matter, however, if this is an integral part of a free and fair multiparty democracy based on the rule of law and the respect for otherness in practice.

It is important, however, to also emphasise that while some of the competitive authoritarian regimes might not meet all criteria for a kind of political governance fully committed to democracy, they at the same time fall short of full-scale authoritarianism. Despite at times manipulating or bypassing democratic rules, 'they are unable to eliminate them or reduce them to a mere façade', as Levitsky and Way (2002, p. 53) suggest. They do not consider, however, despite their earlier insights concerning the popular legitimacy on which the relative strength of a regime could be based, that those executing political hegemony and control might be able to eliminate democratic rules but do not have to. - They can even afford to keep formal democracy as the only game in town, at least officially, without any risk for their dominance. The Namibian case thereby seems to confirm the resource theory of single-party dominance, which maintains that

'dominant parties bias competition in their favour and virtually win elections before election day, typically without resorting to bone-crushing repression or persistent outcome-changing electoral fraud. As a result, it demonstrates a key mechanism for sustaining dominant parties in both democratic and authoritarian regime contexts.' (Greene 2010: 156)

\section{Conclusion}

While this article is only published after the national and presidential elections in Namibia towards the end of 2014, the results of the popular vote will - in line with the just quoted explanation - predictably not require a considerably modified analysis. One does not need any prophetic talents for such an assumption. This relatively safe prognosis simply reinforces the point stressed: Since Independence, the former liberation movement has as a dominant political party consolidated its already then firmly established power base as the result of a number of contributing factors. Namibia therefore represents all features of a dominant party state, which mixes a formal democratic system with authoritarian elements. In the wider international perception, Namibia's political system nevertheless ranks comparatively high within the continent 
on a democratic scale.

At a closer look, however, the democratic image seems less convincing. But the limitations of Namibia's democracy are not exclusively a result for which Swapo ought to be blamed. Its strength, documenting rather coherent mechanisms to maintain control anchored in the authoritarian mind-set of a former liberation movement's "struggle mentality" and the subsequent exploitation of the claim to have been the sole and authentic representative of the Namibian people, is partly also a result of the weakness of a civil society and its political agencies. This includes a political opposition, which does not really aspire more than a few well-paid posts in parliament. Under such circumstances it is difficult to blame only those, who simply make use of the opportunity to expand and consolidate their hegemonic socio-political role in society through their control over the state and its agencies.

Making full use of the opportunities provided at Independence, Swapo's dominance has even cultural features firmly anchored - not least in the mentality of a great deal of ordinary people. Swapo's colours (blue, red and green), the clenched fist, certain liberation and heroic praise songs from the struggle days as well as other insignia firmly underscore the deeply ingrained social fabric of the party in large parts of the Namibian population. While occasionally violating the rules of the game called democracy, Swapo's political office bearers after all have resisted the temptation to do away with the game. - If only, because they can afford to play along most of the time without risking a loss of influence and power. A formally democratic system based on constitutionally enshrined norms and respective institutions contrasts with a policy in practice, which at times is in blatant violation of the governing normative framework without abandoning it. Such peculiar blend, it is suggested, might be described by the only at the surface seemingly contradictory - term democratic authoritarianism, resembling and representing in practice features of both, democracy and authoritarian political rule.

\section{Notes}

*Dag Hammarskjöld Foundation, Uppsala/Sweden, Department of Political Sciences/University of Pretoria and Centre for Africa Studies/University of the Free State, Bloemfontein. Email: Henning.Melber@dhf.uu.se. 
2013. I wish to thank the conference organisers Sebastian Elischer and Matthijs Bogaards for providing me this opportunity. I am also grateful to the two anonymous reviewers, whose observations and comments motivated me to further improve the text.

${ }^{1}$ Slogan on the web site of the Zimbabwe Solidarity Peace Trust established in South Africa by Zimbabwean scholars and activists (http://www.solidaritypeacetrust.org/).

2 This focus is also characteristic for Melber 2013 and 2014 and the chapter in Doorenspleet and Nijzink (2014). Previous efforts include in particular Melber 2003c, 2004 and 2009b.

${ }^{3}$ Recent exceptions are Hartmann (2009), the Namibia chapter in Elischer (2013, pp. 100-139) and my own chapters in the edited volumes by Doorenspleet and Nijzink (2013 and 2014). Though guided by a different research interest, Elischer's many empirical references are suited to underline the general argument in this article.

${ }^{4}$ It features only in two tables in the chapter by Lindberg and Jones (2010), classified as 'democratic dominant'.

${ }^{5}$ These were the MPLA in Angola and FRELIMO in Mozambique (both 1975), ZANU in Zimbabwe (1980), SWAPO in Namibia (1990) and the ANC in South Africa (1994).

${ }^{6}$ The South West African People's Organisation (SWAPO) was founded in 1960, later re-named into SWAPO of Namibia and after Independence in 1990 transformed into Swapo party. It has retained to a large extent its movement character and despite being firmly rooted in the country's northern region formerly called Ovamboland, representing more than half of the population (and hence securing a decisive segment of the electorate) appeals to Namibians from different regions and cultures as well as social classes.

7 This implies that a relevant set of external variables impacting on the constitutive character of Namibian democracy remains ignored. Following the argument of Levitsky and Way $(2002,2010 \mathrm{a}, 2010 \mathrm{~b})$, the particular historical epoch of appeasement as a result of the geopolitical environment after the collapse of the Soviet bloc resulted in a focus on good governance (cf. Abrahamsen 2000) over and above traditional security goals under the bipolarity of the Cold War period. Some of the external factors shaping constitutional ingredients in the transition to Namibian Independence are presented elsewhere (see Melber 2004 and Melber and Saunders 2007). It should also be admitted, that class specific factors influencing policy are also outside of the scope of this article. This does not mean that the relevance and impact of social formations and class interests is denied.

${ }^{8} \mathrm{http}: / /$ www.moibrahimfoundation.org/namibia/

${ }^{9}$ The figures are compiled from various reliable sources, including the official data released by the Directorate of Elections. See for the full party names table 4.

${ }^{10}$ The director of elections for the Election Commission of Namibia (ECN) came under severe criticism after registering the RDP without alerting in advance Swapo and State House that this will happen. In March 2008 he was finally replaced (Maletsky 2008). The members of the ECN are now almost all recruited on the basis of their political trustworthiness. Namibia's permanent representative to the United Nations, earlier unceremoniously dismissed as deputy foreign minister for being accused of supporting the foreign minister Hidipo Hamutenya in his ambitions to become the successor to president Nujoma, came under heavy criticism by party hardliners after the election results in the diplomatic mission in New York in November 2009 were in favour of the new opposition party RDP (with 25 votes against 24 votes for Swapo). Being ultimately recalled by President Pohamba in late 2010 was widely perceived as political punishment (Gurirab 2010).

${ }_{11}$ There were repeated cases of ministries using the facilities for party-political motivated activities, and State House provides the President also for party-political activities with all privileges. The equation that the party is the government and the government is the state is openly put into practice.

${ }^{12}$ UDP activists remain nevertheless active in the Caprivi region, which was renamed into Zambezi in 2013. In April 2012 they planned a demonstration. While following all stipulated procedures in registering with the authorities, permission was categorically denied (Masawi and Konjore 2012). With reference to Diamond (1996, p. 23), Bogaards (2007, p. 187) reminds us that 'bans on particularistic parties violate one of the nine features of liberal democracy'.

${ }^{13}$ http://www.ecn.na/Pages/home.aspx

${ }^{14}$ See Chapter 12 on "Regional and Local Government", which delegates authority to these newly established bodies. 
${ }^{15}$ It has become a habit for Swapo leaders to donate funds to schools, which in turn are given their names or make them the official patron of the particular school benefitting. In September 2012 the leader of the RDP, Hidipo Hamutenya, was awarded the status as patron by a school in his northern home region after he had made some noteworthy donations. As a response, the school was blocked and children prevented from attending. This even provoked a concerned intervention by one of the leading activists among the Swapo party's Youth League, who asked if 'the country (is) being led through emotions (rule of man) or by legitimate leadership and institutions (the rule of law)' (Amupanda 2012).

16 'The Cabinet shall consist of the President, the Prime Minister and such other Ministers as the President may appoint from the members of the National Assembly, including members nominated under Article 46(1)(b) hereof, for the purpose of administering and executing the functions of the Government.

The President may also appoint a Deputy Prime Minister to perform such functions as may be assigned to him or her by the President or the Prime Minister.'

http://www.gov.na/cabinet;jsessionid=351d6161d9c7efc84f5a485d858b. Accessed 10.11.13.

${ }^{17}$ Imagine such a fundraising dinner hosted by President Obama for the Democrats in the White House...

\section{References}

Abrahamsen, Rita. 2000. Disciplining Democracy: development discourse and good governance in Africa. London: Zed Books.

Amupanda, Job S. 2012. School Patron scandal; Iyambo must conspicuously lead. The Villager, 30 September

http://www.thevillager.com.na/articles/2580/School-Patron-scandal--Iyambo-mustconspicuously-lead/. Accessed 25.10.13.

Art, David. 2012. What Do We Know About Authoritarianism After Ten Years? Comparative Politics 44(3): 351-371.

Basedau, Matthias. 2007. Do Party Systems Matter for Democracy? A Comparative Study of 28 Sub-Saharan Countries. In Votes, Money and Violence. Political Parties and Elections in Sub-Saharan Africa, eds. Mattias Basedau, Gero Erdmann and Andreas Mehler, 105143. Uppsala: Nordic Africa Institute.

Bogaards, Mathijs. 2000. Crafting Competitive Party Systems: Electoral Laws and the Opposition in Africa. Democratization 7(4): 163-190.

Bogaards, Mathijs. 2004. Counting Parties and Identifying (Dominant) Party Systems in Africa. European Journal of Political Research 43(2): 173-197.

Bogaards, Mathijs. 2007. Electoral Systems, Party Systems and Ethnicity in Africa. In Votes, Money and Violence. Political Parties and Elections in Sub-Saharan Africa, eds. Mattias Basedau, Gero Erdmann and Andreas Mehler, 168-193. Uppsala: Nordic Africa Institute.

Bogaards, Mathijs. 2009. How to Classify Hybrid Regimes? Defective Democracy and Electoral Authoritarianism. Democratization 16(2): 399-423. 
Bogaards, Mathijs and Francoise Boucek, eds. 2010. Dominant Political Parties and Democracy. Concepts, measures, cases, and comparisons. London and New York: Routledge.

Cooper, Ian. 2014. It's My Party: Opposition Politics, Party Motivation and Electoral Strategy in Namibia. Journal of Southern African Studies 40(1): 111-127.

Coppedge, Michael and John Gerring, et. al. 2011. Conceptualizing and Measuring Democracy: A New Approach. Perspectives on Politics 9(2): 247-267.

Dahl, Robert A. 1971. Polyarchy: Participation and Opposition. New Haven: Yale University Press.

Dahl, Robert A. 1998. On Democracy. New Haven and London: Yale University Press.

Diamond, Larry. 1996. Is the Third Wave Over? Journal of Democracy 7(3): 21-37.

De Jager, Nicola and Pierre du Toit, eds. 2013. Friend or Foe? Dominant party systems in southern Africa. Insights from the developing world. Cape Town: UCT Press and Tokyo/New York/Paris: United Nations University Press.

Dobell, Lauren. 1998. SWAPO's Struggle for Namibia, 1960-1991. War by other means. Basel: P. Schlettwein.

Doorenspleet, Renske and Lia Nijzink. 2013a. Why One-Party Dominance Endures in Some Democracies but Not Others. In One-Party Dominance in African Democracies, eds. Renske Doorenspleet and Lia Nijzink, 195-207. Boulder, CO: Lynne Rienner.

Doorenspleet, Renske and Lia Nijzink. 2013b. One-Party Dominance in African Democracies: A Framework for Analysis. In One-Party Dominance in African Democracies, eds. Renske Doorenspleet and Lia Nijzink, 1-23. Boulder, CO: Lynne Rienner.

Doorenspleet, Renske and Lia Nijzink, eds. 2014. Political Parties, Party Systems and Democracy in Africa. Basingstoke: Palgrave/Macmillan.

Dorman, Sara Rich. 2006. Post-Liberation Politics in Africa: Examining the Political Legacy of Struggle. Third World Quarterly 27(6): 1085-1101

Du Pisani, André. 2013. The politics and resource endowment of party dominance in Namibia: The past as the present and the future? In Friend or Foe? Dominant party systems in southern Africa. Insights from the developing world, eds. Nicola de Jager and Pierre du Toit, 132-148. Cape Town: UCT Press and Tokyo/New York/Paris: United Nations University Press.

Du Pisani, André and William A. Lindeke. 2009. Namibia. In KAS Democracy Report 
2009: Parties and Democracy Vol. II, ed. Konrad-Adenauer-Stiftung, 17-32. St. Augustin: Konrad Adenauer Stiftung.

Erdmann, Gero, Matthias Basedau and Andreas Mehler. 2007. Conclusion. The Research Agenda Ahead. In Votes, Money and Violence. Political Parties and Elections in SubSaharan Africa, eds. Mattias Basedau, Gero Erdmann and Andreas Mehler, 276-292. Uppsala: Nordic Africa Institute

Elischer, Sebastian. 2013. Political Parties in Africa: Ethnicity and Party Formation. Cambridge: Cambridge University Press.

Fanon, Frantz. 2001. The Wretched of the Earth. Harmondsworth: Penguin (French original 1961).

Galtung, Johan. 1969. Violence, Peace and Peace Research. Journal of Peace Research 6(3): 167-191.

Gilley, Bruce. 2010. Democratic Triumph, Scholarly Pessimism. Journal of Democracy 21(1): 160-167.

Giollabhuí, Shane Mac. 2011. How things fall apart: Candidate selection and the cohesion of dominant parties in South Africa and Namibia. Party Politics 19(4): 577-600.

Greene, Kenneth F. 2010. A resource theory of single-party dominance. The PRI in Mexico. In Dominant Political Parties and Democracy. Concepts, measures, cases, and comparisons, eds. Matthijs Bogaards and Francoise Boucek, 155-174. London and New York: Routledge.

Gurirab, Theo. 2010. Mbuende recall raises eyebrows. The Namibian Sun, 29 November http://sun.com.na/node/3424. Accessed 25.10.13.

Gyimah-Boadi, E. 2007. Political Parties, Elections and Patronage. Random Thoughts on Neo-Patrimonialism and African Democratization. In Votes, Money and Violence. Political Parties and Elections in Sub-Saharan Africa, eds. Mattias Basedau, Gero Erdmann and Andreas Mehler, 21-33. Uppsala: Nordic Africa Institute.

Hartmann, Christof. 2009. Democracy as a fortuitous by-product of Independence: UN intervention and democratization in Namibia. Taiwan Journal of Democracy 5(1): 27-50.

Hunter, Justine, ed. 2005. Spot the Difference. Namibia's Political Parties Compared. Windhoek: Namibia Institute for Democracy.

IRIN. 2006. Namibia: Caprivi political party declared illegal. IRIN News, 11 September http://www.irinnews.org/report/60892/namibia-caprivi-political-party-declaredillegal. Accessed 25.10.13. 
Kaapama, Phanuel, Lesley Blaauw, Bernie Zaaruka and Esau Kaakunga. 2007. Consolidating Democratic Governance in Southern Africa: Namibia. Johannesburg: EISA (EISA Research Report; no. 34).

Levitsky, Steven and Lucan A. Way. 2002. Elections Without Democracy. The Rise of Competitive Authoritarianism. Journal of Democracy 13(2): 51-65.

Levitsky, Steven and Lucan A. Way. 2010a. Competitive Authoritarianism: Hybrid Regimes After the Cold War. Cambridge: Cambridge University Press.

Levitsky, Steven and Lucan A. Way. 2010b. Beyond Patronage: Ruling Party Cohesion and Authoritarian Stability. Paper prepared for the American Political Science Association Annual Meeting. Washington, DC, 2-5 September.

Leys, Colin and John S. Saul et. al. 1995. Namibia's Liberation Struggle. The Two-edged Sword. London: James Currey.

Lindberg, Staffan. 2004. The Democratic Qualities of Competitive Elections: Participation, Competition and Legitimacy in Africa. Commonwealth \& Comparative Politics 42(1): 61-105.

Lindberg, Staffan. 2006. The Surprising Significance of African Elections. Journal of Democracy 17(1): 139-151.

Lindberg, Staffan I. and Jonathan Jones. 2010. Laying a foundation for democracy or undermining it? Dominant parties in Africa's burgeoning democracies. In Dominant Political Parties and Democracy. Concepts, measures, cases, and comparisons, eds. Matthijs Bogaards and Francoise Boucek, 196-219. London and New York: Routledge.

Lipset, Seymor M. 2000. The Indispensability of Political Parties. Journal of Democracy 11(1): 48-55.

Maletsky, Christof. 2008. ECN suspends Kanime. The Namibian, 10 March http://www.namibian.com.na/indexx.php?archive $\mathrm{id}=46531$ \&page type=archive story detail\&page=3722. Accessed 25.10.13.

Maletsky, Christof. 2009. Pohamba appeals to peace and unity during five-day tour. The Namibian, 9 July http://www.namibian.com.na/indexx.php?archive id=55340\&page type=archive story detail\&page=8. Accessed 25.10.13.

Masawi, Tirivangani and Romanus Konjore. 2012. Caprivi rises again. The Villager, 2026 April http://www.thevillager.com.na/news article.php?id=1439\&title=Caprivi $\% 20$ rises $\% 20$ \%20again. Accessed 25.10.13. 
Mehler, Andreas. 2007. Political Parties and Violence in Africa: Systematic Reflections against Empirical Background. In Votes, Money and Violence. Political Parties and Elections in Sub-Saharan Africa, eds. Mattias Basedau, Gero Erdmann and Andreas Mehler, 194-223. Uppsala: Nordic Africa Institute.

Melber, Henning, ed. 2003a. Limits to Liberation in Southern Africa: The Unfinished business of democratic consolidation. Cape Town: HSRC Press.

Melber, Henning. 2003b. "Namibia, land of the brave": Selective memories on war and violence within nation building. In Rethinking Resistance: Revolt and Violence in African History, eds. Jon Abbink, Mirjam de Bruijn and Klaas van Walraven, 305-327. Leiden and Boston: Brill (African Dynamics; 2).

Melber, Henning, ed. 2003c. Re-examining Liberation in Namibia. Political Culture Since Independence. Uppsala: The Nordic Africa Institute.

Melber, Henning. 2004. Decolonization and democratisation: The United Nations and Namibia's transition to democracy. In The UN role in promoting democracy: Between ideals and reality, eds. Edward Newman, Roland Rich, 233-257. Tokyo/New York/Paris: United Nations University Press.

Melber, Henning. 2005a. Namibia's Past in the Present: Colonial Genocide and Liberation Struggle in Commemorative Narratives. South African Historical Journal 54(1): 91-111.

Melber, Henning. 2005b. People, Party, Politics and Parliament: Government and Governance in Namibia. In African Parliaments: Governance and Government, ed. Mohamed Salih, 142-161. Basingstoke: Palgrave Macmillan (also Cape Town: HSRC Press 2006).

Melber, Henning. 2006. "Presidential indispensability" in Namibia: moving out of office but staying in power? In Legacies of power: Leadership change and former presidents in African politics, eds. Roger Southall and Henning Melber, 98-119. Cape Town: HSRC Press and Uppsala: The Nordic Africa Institute.

Melber, Henning. 2009a. Southern African Liberation Movements as Governments and the Limits to Liberation. Review of African Political Economy 36(121): 453-461.

Melber, Henning. 2009b. Governance, Political Culture and Civil Society Under a Civil Liberation Movement in Power: the case of Namibia. In Southern Africa: Civil Society, Politics and Donor Strategies. Angola and its neighbours, eds. Nuno Vidal with Patrick Chabal, 199-212. Luanda and Lisbon: Media XXI \& Firmamento.

Melber, Henning. 2009c. One Namibia, One Nation? The Caprivi as a contested territory. Journal of Contemporary African Studies 27(4): 463-481. 
Melber, Henning. 2010. Namibia's national assembly and presidential elections 2009: Did democracy win? Journal of Contemporary African Studies 28(2): 203-214.

Melber, Henning. 2011a. Liberation Movements as Governments in Southern Africa - on the Limits to Liberation. Strategic Review for Southern Africa 33(1): 78-102.

Melber, Henning. 2011b. Beyond Settler Colonialism Is Not Yet Liberation. On the Limits to Liberation in Southern Africa. Socialist History 39: 81-91.

Melber, Henning. 2013. Namibia: Cultivating the Liberation Gospel. In One Party Dominance in African Democracies, eds. Renske Doorenspleet and Lia Nijzink, 49-72. Boulder, CO: Lynne Rienner.

Melber, Henning. 2014. Understanding Namibia. The Trials of Independence. London: Hurst.

Melber, Henning and Christopher Saunders. 2007. Conflict mediation in decolonisation: Namibia's transition to Independence. Africa Spectrum (42)1: 73-94.

Ndlovu-Gathseni, Sabelo J. and Finex Ndhlovu, eds. 2013. Nationalism and National Projects in Southern Africa. New critical reflections. Pretoria: Africa Institute of South Africa.

Ntinda, Asser. 2013a. Zoom In: Professor Horn's pathetic theories. Namibia Today, http://www.swapoparty.org/zoom in 105.html. Accessed 25.10.13.

Ntinda, Asser. 2013b. Zoom In: SWAPO Party government under attack. Namibia Today, http://www.swapoparty.org/zoom in 129.html. Accessed 02.11.13.

Nujoma, Sam. 2010. Where we came from. Speech delivered to the SWAPO Youth League congress in 2010. Undated document, posted at the SWAPO Party web site: http://www.swapoparty.org/where we came from.html. Accessed 25.10.13.

Ramphele, Mamphela. 2012. Does the ANC centenary mark progress in socio-economic equity and democratic freedom for the majority? Opening Lecture on "Negotiating the Roles of Liberation Movement and Ruling Party" at the centre for African Studies, University of Basel, 21 September (published as: "We need to generate a momentum amongst citizens to demand change in the quality of governance", Timeslive, 25 September, at http://m.timeslive.co.za/ilive/?articleId=6670335)

Randall, Vicky. 2007. Political Parties in Africa and the Representation of Social Groups. In Votes, Money and Violence. Political Parties and Elections in Sub-Saharan Africa, eds. Mattias Basedau, Gero Erdmann and Andreas Mehler, 82-104. Uppsala: Nordic Africa Institute.

Regan, Patrick M. and Errol A. Henderson. 2002. Democracy, Threats and Political 
Repression in Developing Countries: Are Democracies Internally Less Violent? Third World Quarterly 23(1): 119-136.

Rudebeck, Lars. 2002. Beyond Democratic Constitutionalism: On the Twofold Meaning of Democracy and Democratisation. African Sociological Review 6(1): 173-180.

Rudebeck, Lars. 2011. Electoral Democratisation in Post-Civil War Guinea-Bissau 19992008. Uppsala: Nordic Africa Institute (Discussion Paper 66).

Salih, Mohamed A. 2003. African Political Parties: Evolution, Institutionalism and Governance. London: Pluto Press

Sartori, Giovanni. 1976. Parties and Party Systems. A Framework for Analysis. Cambridge: Cambridge University Press

Sims, Bryan M. and Monica Koep, eds. 2012. Unfinished Business: democracy in Namibia. Pretoria: Idasa

Southall, Roger. 2013. Liberation Movements in Power. Party \& State in Southern Africa. Woodbridge: James Currey and Pietermaritzburg: University of KwaZulu-Natal Press.

Southall, Roger. 2014. Threats to Constitutionalism by Liberation Movements in Southern Africa. Africa Spectrum 49(1): 79-99.

Suttner, Raymond. 2008. The ANC Underground in South Africa. Auckland Park: Jacana

SWAPO Party. 2009. In the Spotlight.

http://www.swapoparty.org/spotlight 2009 namibia presidential and national assem bly elections results.html. Accessed 25.10.13.

The Namibian. 12.11.12. $N \$ 100 \mathrm{k}$ dinner raises eyebrows.

http://www.namibian.com.na/indexx.php?archive $\mathrm{id}=110780$ \&page type=archive stor y detail\&page=586. Accessed 25.10.13.

Tjihenuna, Theresia. 2013. Babylon residents allege discrimination by Swapo. The Namibian, 6 November.

http://www.namibian.com.na/indexx.php?id=5734\&page type=story detail\&category id=1\#sthash.jFPd0mN1.dpuf. Accessed 06.11.13.

Ua-Ndjarakana, Mbeuta. 2009. President Is Head Of State 24/7. The Namibian, 17 July http://www.namibian.com.na/indexx.php?archive id=55614\&page type=archive story detail\&page=1. Accessed 25.10.13. 